\title{
Beauty food activities of wild-cultivated Ginseng (Panax ginseng C.A. Meyer) ground part
}

\author{
Myeong-Wook Kim ${ }^{1} \cdot$ Eun-Ho Lee ${ }^{2} \cdot$ Ye-Jin $\mathrm{Kim}^{2} \cdot$ Tae-Soon Park $^{3} \cdot$ Young-Je Cho $^{2}$ \\ 산양삼(Panax ginseng C.A. Meyer) 지상부위의 미용 식품 활성
}

김명욱 ${ }^{1} \cdot$ 이은호 ${ }^{2} \cdot$ 김예진 $^{2} \cdot$ 박태순 $^{3} \cdot$ 조영제 $^{2}$

Received: 11 September 2017 / Accepted: 4 January 2018 / Published Online: 31 March 2018

(C) The Korean Society for Applied Biological Chemistry 2018

\begin{abstract}
This study aimed to investigate the beauty food activities of wild-cultivated ginseng (Panax ginseng C.A. Meyer). wild-cultivated ginseng extracts were analyzed for antioxidant, skin whitening, anti-wrinkle effect was measured in water and $70 \%$ ethanol extract. The 1,1-diphenyl-2-picrylhydrazyl (DPPH) free radical scavenging and 2,2'-azinobis (3-ethylbenzothiazoline6-sulfonic acid) (ABTS) radical decolorization activities of water and $70 \%$ ethanol extracts were 16.69 and $2.18 \%$ as well as 4.04 and $3.25 \%$ at a solid content of $200 \mu \mathrm{g} / \mathrm{mL}$, respectively. The antioxidant protection factors $(\mathrm{PF})$ of water and $70 \%$ ethanol extracts at a solid content of $200 \mu \mathrm{g} / \mathrm{mL}$ were $1.06 \mathrm{PF}$ and 1.09 $\mathrm{PF}$, respectively. Thiobarbituric acid reactive substance (TBARs) were both $96 \%$ at a solid content of $200 \mu \mathrm{g} / \mathrm{mL}$. As PF and TBARs showed higher activity than DPPH and ABTS, we could know that antioxidant activity in the lipophilic component of
\end{abstract}

Young-Je Cho $(\varangle)$

E-mail: yjcho@knu.ac.kr

${ }^{1}$ Gyeongbuk institute for marine bio-industry, 688-3, Hujeong-ri, Jukbyeon, Uljin, Gyeongbuk 36315, Republic of Korea

${ }^{2}$ School of Food science \& Biotechnology/Food \& Bio-Industry Research Institute, Kyungpook National University, 80 University Street, Bukgu, Daegu 41566, Republic of Korea

${ }^{3}$ National Development Institute of Korea Medicine, Gyeongsan 38540, Republic of Korea

This is an Open Access article distributed under the terms of the Creative Commons Attribution Non-Commercial License (http://creativecommons. org/licenses/by-nc/3.0/) which permits unrestricted non-commercial use, distribution, and reproduction in any medium, provided the original work is properly cited. wood-cultivated ginseng were superior to water-soluble component of wood-cultivated ginseng. Tyrosinase inhibitory activity was 10.97 and $52.39 \%$ in water and $70 \%$ ethanol extracts at a solid content of $200 \mu \mathrm{g} / \mathrm{mL}$. The collagenase and elastase inhibitory activities as anti-wrinkle effect were 15.71 and $20.43 \%$ in water extracts as well as 32.26 and $86.74 \%$ in $70 \%$ ethanol extract at a solid content of $200 \mu \mathrm{g} / \mathrm{mL}$. The results show that anti-wrinkle effect was the best among the other experiments. This extracts from wood-cultivated ginseng, therefore, seems to be a potent beauty food resource against wrinkles.

Keywords Anti-oxidant $\cdot$ Anti-wrinkle $\cdot$ Beauty food $\cdot$ Panax ginseng C.A. Meyer · Whitening effect

\section{서 론}

미용 식품이란 우리나라에서 그 용어적 개념이나 의미가 정확 히 정의되어 있지 않은데(Park 2007), 식품 및 약리성 식물 중 미용 활성을 가지고 있어 이를 기능성 원료로 활용할 수 있는 식품 소재를 뜻한다. 최근 소비자들은 건강뿐 만 아니라, 미용 을 위한 기능성 제품을 요구하고 있다(Jeong 등, 2013). 특히, 노화 억제와 관련된 피부 주름 개선, 항산화와 같은 기능에 관 심이 집중되고 있어(Kim 2007) 피부 미용의 시장규모가 점점 커지고 있으며, 결국 미용 식품을 활용한 산업이 앞으로 더욱 활발해질 것으로 전망된다.

인삼(Panax ginseng C.A. Meyer)이란, 다양한 종류의 삼을 총칭하며 두릅나무과(Araliaceae) 인삼속에 속하는 음지성 식물 로 약 2,000 년 전부터 동양권에서 오랫동안 생약으로 많이 사 
용되어 왔으며, 최근에는 이를 이용한 다양한 기능성 제품들이 출시되고 있다(Oh 등, 1998). 인삼(cultivated ginseng)은 밭에서 재배한 인삼(cultivated ginseng in the field)과 야생상태에서 재 배한 장뇌삼, 산양삼으로 분류되는데 인삼에서도 산양삼(wildcultivated ginseng)과 장뇌삼을 혼동하여 사용하는 많아, 2012년 산림청에서는 이들 삼 종류에 대한 용어를 재정립하여 모두 산 양삼으로 부르도록 규정하고 있다(Lee 2011).

산양삼은 인삼(cultivated ginseng)이 자연상태에서 재배된 것 으로, 약리 및 생리활성 면에서 재배된 인삼보다 효과가 더 높 은 것으로 알려져 있다(Kim과 $\operatorname{Kim} 2005)$. 또한, 산양삼은 미 용 활성을 가지는 식물소재로, 뿌리 부분을 이용하여 자외선 차 단(Lee 등, 2003; Kang 등, 2009), 미백효과(Kim 2015), 아토 피 완화효과(Park 등, 2010), 피부 탄력(Gezzi 등, 1986), 수화 성 증가(Curri 등, 1986) 및 주름생성 억제(Kim 등, 2007; Kwok 등, 2012) 등 여러가지 연구가 보고되어 있으며, 이를 통 해 화장품의 개발에 적용되고 있다. 특히 최근에는 지상부인 잎 과 줄기에 대한 관심이 증대되고 있지만(Bae 2010), 아직까지 산양삼의 뿌리에 비해 잎과 줄기에 대한 연구가 미흡한 실정이 다(Yeom 등, 2016). 따라서, 본 연구에서 산양삼 지상부가 가 지는 미용 활성을 알아보기 위해서 elastase, tyrosinase, collagenase 등의 미용 활성과 관련된 실험을 진행하여 이들의 효능을 확인하였으며, 향후 다양한 기능성 원료 개발에 사용될 기초 자료로 제공하고자 한다.

\section{재료 및 방법}

\section{실험 재료}

본 실험에서 사용한 산양삼(Panax ginseng C.A. Meyer)은 2016년 경북 영주 지방의 산양삼 재배지에서 직접 구입한 후, 뿌리부분을 제거한 지상부(잎, 줄기 혼합물)만을 분리하여 $45^{\circ} \mathrm{C}$ dry oven (FO-600M, Jeiotech, Daejeon, Korea)에서 건조 시킨 후 $40 \mathrm{mesh}$ 로 분쇄하여 $4{ }^{\circ} \mathrm{C}$ 로 저장하며 실험에 사용하였다.

\section{추출물의 제조}

시료 추출물은 열수 추출물의 경우 산양삼 지상부 건조분말 $1 \mathrm{~g}$ 을 증류수 $200 \mathrm{~mL}$ 에 침지하여 추출물이 $100 \mathrm{~mL}$ 가 될 때까지 가열, 증발시킨 후 냉각하여 상온에서 24시간 동안 교반 추출 하였으며, 에탄올 추출물은 산양삼 지상부 건조분말 $1 \mathrm{~g}$ 에 $70 \%$ 에탄올 $100 \mathrm{~mL}$ 를 추출용매로 가하여 상온에서 24 시간 동안 교 반 추출하였다. 각 추출물은 Whatman No. 1 filter paper (Whatman Inc., Piscataway, NJ, USA)로 여과한 후 동결건조기 (FD8518, Ilshinbiobase Co., Dongducheon, Korea)를 사용하여 $-85{ }^{\circ} \mathrm{C}$ 에서 동결 건조하였다. 이후 실험은 동결건조물을 증류수 에 녹여 중량 비 농도 $(50-200 \mu \mathrm{g} / \mathrm{mL})$ 로 맞추어 진행하였다.

\section{산양삼 지상부 추출물의 항산화 효과}

항산화 효과를 측정하기 위해 1,1-diphenyl-2-picrylhydrazyl (DPPH), 2,2'-azinobis (3-ethylbenzothiazoline-6-sulfonic acid (ABTS), antioxidant protection factor (PF), thiobarbituric acid reactive substances (TBARs)를 측정하였다. DPPH radical에 대 한 소거활성은 Blios(1958)의 방법에 준하여 측정하였으며, 저
해율 $(\%)$ 은 (1-반응구의 흡광도/대조구의 흡광도 $) \times 100$ 으로 계산 하였다. ABTS radical cation decolorization의 측정은 Fellegrin 등(1999)의 방법에 준하여 측정하였고, 저해율 $(\%)$ 은 (1-반응구 의 흡광도/대조구의 흡광도 $) \times 100$ 으로 계산하였다. $\mathrm{PF}$ 는 Andarwulan과 Shetty(1999)의 방법에 준하여 측정하였으며, PF 는 반응구의 흡광도/대조구의 흡광도 비로 계산하였다. TBARs 측정은 Buege와 Aust(1978)의 방법에 준하여 측정하였으며, 저 해율 $(\%)$ 은 (1-반응구의 TBARs $\mu \mathrm{M} /$ 대조구의 TBARs $\mu \mathrm{M}) \times 100$ 으로 계산하였다. 시료의 항산화 효과는 항산화 물질로 잘 알 려진 butylated hydroxy toulene (BHT)를 positive control로 사용하여 비교하였다.

\section{산양삼 지상부 추출물의 tyrosinase 저해효과}

Tyrosinase 저해활성 측정은 Hearing(1987)의 방법에 준하여 측 정하였다. 반응구에는 $0.1 \mathrm{M}$ sodium phosphate buffer $(\mathrm{pH}$ 6.8) $2.3 \mathrm{~mL}$ 와 기질액 $1.5 \mathrm{mM} \mathrm{L-tyrosine} \mathrm{용액} 0.4 \mathrm{~mL}$ 의 혼합 액에 $250 \mathrm{U} / \mathrm{mL}$ mushroom tyrosinase (Sigma-Aldrich Co., St. Louis, MO, USA) $0.1 \mathrm{~mL}$ 와 시료를, 대조구에는 시료 대신 증 류수를 $0.2 \mathrm{~mL}$ 씩 첨가하여 $37^{\circ} \mathrm{C}$ 에서 20 분간 반응시킨 후 흡광 도 $475 \mathrm{~nm}$ 에서 측정하였다. 저해율 $(\%)$ 은 (1-반응구의 흡광도/ 대조구의 흡광도 $) \times 100$ 으로 계산하였다.

\section{Elastase 저해활성 측정}

Elastase 저해활성 측정은 James 등(1996)의 방법에 준하여 측 정하였다. 반응구는 $0.2 \mathrm{M}$ Tris- $\mathrm{HCl}$ buffer $(\mathrm{pH} 8.0) 1 \mathrm{~mL}$ 에 기질액 $0.8 \mathrm{mM} \mathrm{N}$-succinyl-(Ala) $)_{3}$ - - -nitroanilide 용액 $0.1 \mathrm{~mL}$ 의 혼합액에 $1.0 \mathrm{U} / \mathrm{mL}$ porcine pancreatine elastase (Sigma-Aldrich Co.) 효소용액 $0.1 \mathrm{~mL}$ 와 시료를, 대조구에는 시료 대신 증류수 를 $0.1 \mathrm{~mL}$ 씩 첨가하여 $25^{\circ} \mathrm{C}$ 에서 20 분간 반응시킨 후, $\rho$ nitroaniline 생성량을 흡광도 $410 \mathrm{~nm}$ 에서 측정하였다. 저해율 $(\%)$ 은 (1-반응구의 흡광도/대조구의 흡광도 $) \times 100$ 으로 계산하였다.

\section{Collagenase 저해활성 측정}

Collagenase 저해활성 측정은 Wunsch와 Heidrich(1963)의 방법 에 준하여 측정하였다. 반응구는 $0.1 \mathrm{M}$ Tris- $\mathrm{HCl}$ buffer $(\mathrm{pH} 7.5)$ 에 $4 \mathrm{mM} \mathrm{CaCl}$ 를 첨가하여 4-phenylazobenzyl oxycarbonylPro-Leu-Gly-Pro-D-Arg $(0.3 \mathrm{mg} / \mathrm{mL})$ 를 녹인 기질액 $0.25 \mathrm{~mL}$ 와 시료 $0.1 \mathrm{~mL}$ 의 혼합용액에 $0.2 \mathrm{mg} / \mathrm{mL}$ collagenase (SigmaAldrich Co.) $0.15 \mathrm{~mL}$ 를 첨가하고, 대조구에는 시료 대신 증류 수 $0.1 \mathrm{~mL}$ 를 첨가하여 실온에서 20 분간 방치한 후 $6 \%$ citric acid $0.5 \mathrm{~mL}$ 를 넣어 반응을 정지시키고, ethyl acetate $2 \mathrm{~mL}$ 를 첨가하고 $320 \mathrm{~nm}$ 에서 흡광도를 측정하였다. 저해율 $(\%)$ 은 (1-반 응구의 흡광도/대조구의 흡광도) $\times 100$ 으로 계산하였다.

\section{통계처리}

본 실험은 3회 반복하여 측정하였고, 자료의 통계처리는 SPSS 22 for windows (Statistical Package for Social Science, Chicago, IL, USA)프로그램을 이용하여 평균 표준편차(mean \pm standard deviation)로 표시하였다. 시료 간의 유의차는 분산분 석(ANOVA)과 Duncan의 다중범위검정(Duncan's multiple range test)을 실시하여 $95 \%$ 신뢰구간에서 검증하였다. 

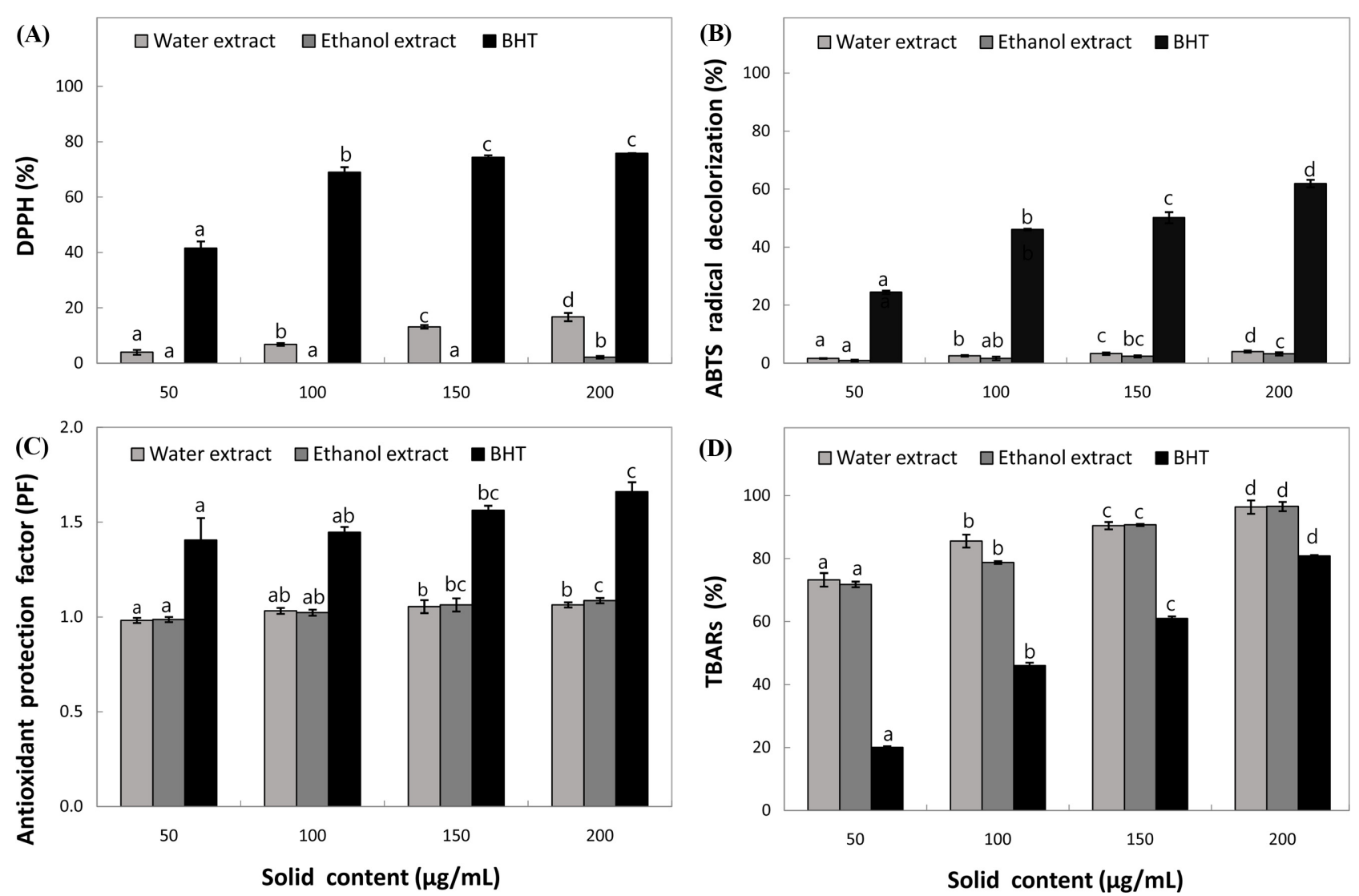

Fig. 1 Antioxidant activity of water and ethanol extracts from Panax ginseng C.A. Meyer. (A): DPPH, (B): ABTS, (C) PF, (D): TBARs. Means with different superscript letters are significantly different at $p<0.05$ by a Ducan's multiple range tests $(n=3)$

\section{결과 및 고찰}

\section{산양삼 지상부 추출물의 항산화 효과}

산양삼 지상부 추출물의 항산화능을 알아보기 위하여 $\mathrm{DPPH}$, ABTS, PF, TBARs 활성을 측정하였다. Free radical은 인체 내 에 존재하는 지질 또는 단백질과 결합하여 노화를 일으킨다. 페 놀성 화합물은 이러한 free radical을 환원 및 상쇄시키는 능력 을 가져 인체 내에서 free radical에 대한 항산화의 척도로 이용 할 수 있다(Kim 등, 1995). 자색의 안정한 free radical인 DPPH 를 사용하는 DPPH법은 sulfur-containing amino acid와 BHA 등에 의해 환원되어 탈색되는 원리를 이용한 실험으로, 다양한 천연물로부터 추출된 수용성 물질의 항산화능을 탐색하는데 많 이 이용 된다. 본 실험에서 $50-200 \mu \mathrm{g} / \mathrm{mL}$ 의 농도구간으로 맞춘 산양삼 지상부 추출물의 항산화능을 $\mathrm{DPPH}$ 법으로 측정한 결과, Fig. 1-A와 같이 나타났다. 열수 추출물은 DPPH 소거능은 크 게 높지 않았으나 전 농도구간에서 3.95-16.69\%로 농도 의존적 으로 증가하였고, 에탄올 추출물은 전 농도구간에서 활성을 보 이지 않았다. Lee 등(2004)의 실험에서 인삼의 줄기, 잎 에탄올 추출물에 대해 $\mathrm{DPPH}$ 법을 진행한 결과 각각 $-11.7,7.7 \%$ 를 나 타내었다. 산양삼과 마찬가지로 인삼의 지상부 또한 낮은 활성 을 나타내지만 산양삼 지상부 에탄올 추출물보다는 높은 활성 을 나타내었다. 산양삼의 열수 추출물과 에탄올 추출물의 DPPH 소거능을 비교하였을 때, 산양삼 지상부 열수 추출물의 항산화
능이 더 우수한 것으로 확인되었지만 전체적으로 수치가 낮아 $\mathrm{DPPH}$ 소거능이 뛰어나다고 볼 수는 없었다. $\mathrm{ABTS}$ 법은 $\mathrm{ABTS}$ 와 potassium persulfate의 반응으로 생성된 $\mathrm{ABTS}^{+}$radical이 청록색에서 연두색으로 탈색되는 원리를 이용한 실험으로, 수용 성 물질의 항산화능을 측정할 수 있다(Kim 등, 2015). 산양삼 지상부 추출물의 항산화능을 $50-200 \mu \mathrm{g} / \mathrm{mL}$ 의 농도구간에서 $\mathrm{ABTS}$ 법으로 측정한 결과, Fig. 1-B에서와 같이 열수 추출물과 에탄올 추출물 모두 낮은 수치를 나타내었다. DPPH와 ABTS 로 측정한 산양삼 지상부 추출물의 항산화능은 모두 항산화제 로 잘 알려진 BHT와 비교하면 미미한 수준으로 수용성 물질 에 대한 항산화성은 높지 않은 것으로 확인되었다. 지질 산화 과정에서 생성되는 peroxy radical과 $\beta$-carotene의 반응으로 생 성된 불활성 물질은 free radical에 의한 연쇄 반응을 정지시키 는데(Cho 등, 2006), 이러한 원리를 이용하여 산양삼 지상부 추 출물의 지용성 물질에 대한 항산화능을 측정하였다. 그 결과, Fig. 1-C에서와 같이 $50-200 \mu \mathrm{g} / \mathrm{mL}$ 의 농도구간에서 열수 추출 물의 경우 0.98-1.06 PF, 에탄올 추출물의 경우 0.99-1.09 PF로 효능이 비슷한 것으로 측정되었으며, 농도 의존적인 양상은 나 타내지 않았다. 2-thiobarbituric acid (TBA) 시약을 이용하는 TBARs법은 PF법과 유사하게 추출물의 지용성 물질에 대한 항 산화능을 확인할 수 있는데, TBA 시약이 불포화 지방산의 자 동산화 중 생성되는 반응성이 높은 malondialdehyde (MDA)와 반응하면 적색의 복합체를 생성하는데, 이들의 함량을 측정하여 


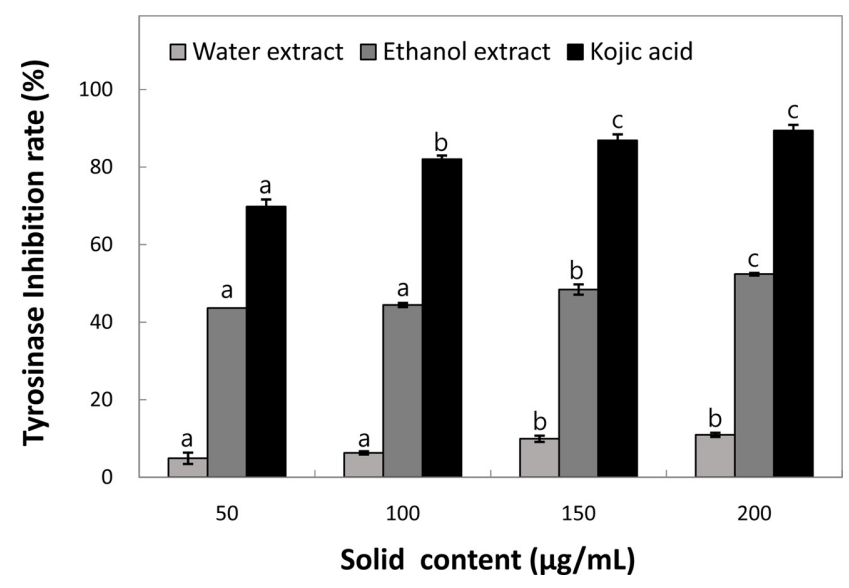

Fig. 2 Inhibitory effect of water and ethanol extracts from Panax ginseng C.A. Meyer on tyrosinase. Ethanol extract showed higher tyrosinase inhibitory effect than water extract. Means with different superscript letters are significantly different at $p<0.05$ by a Duncan's multiple range tests $(\mathrm{n}=3)$

확인할 수 있다(Cojocaru 등, 2004; Cheon 등, 2008). 이러한 원리를 이용하여 TBARs를 측정한 결과 Fig. 1-D에서와 같이 열수와 에탄올 추출물 모두 $50-200 \mu \mathrm{g} / \mathrm{mL}$ 의 농도구간에서 $70 \%$ 이상의 높은 활성을 나타내었고, 각각 73.27-96.36, 71.80$96.55 \%$ 로 농도 의존적으로 증가하는 양상을 보였다. Positive control인 BHT와 비교하였을 때 같은 농도 구간에서 20.06$80.84 \%$ 로 산양삼 지상부 추출물의 항산화능이 더 우수한 것을 확인할 수 있었다. 또한 Pan 등(2013)의 실험에서는 산양삼 지 하부 열수 추출물의 TBARs 값은 $5000 \mu \mathrm{g} / \mathrm{mL}$ 의 농도에서 $31.9-49.4 \%$ 로, 본 실험에서는 $200 \mu \mathrm{g} / \mathrm{mL}$ 에서 활성이 $96.36 \%$ 를 나타내었으므로 산양삼 지상부의 항산화능이 더 우수한 것을 알 수 있었다. 항산화 효과를 보기 위해 실시한 4가지 실험의 결 과를 통하여 산양삼 지상부 추출물은 수용성 물질보다 지용성 물질에 대한 항산화능이 매우 높은 것을 확인할 수 있었다.

\section{산양삼 지상부 추출물의 tyrosinase 저해활성}

Melanin은 자외선으로부터 피부를 보호하기 위해 생성되는데, 그 종류는 eumelanin, phenomelanin, allomelanin이 있다. 이 중에서 eumelanin과 phenomelanin이 피부 색에 영향을 미친다 (Kazumasa와 Shosuke 2002). L-Tyrosine이 tyrosinase에 의해 L-3,4-dihydroxy phenylalanine (DOPA)이 되고, 이어서 DOPA 는 hydroxylation의 과정을 통해 L-dopaquinone과 dopachrome 으로 전환되어 최종적으로 피부 흑화의 원인이 되는 melanin을 형성한다. 여기서 tyrosinase는 melanin 합성 속도를 결정하기 때문에 melanin 합성을 저해시키기 위해서는 tyrosinase 활성을 억제해야 한다(Shosuke 2003). 이러한 이유로 tyrosinase 저해활 성은 미백성분의 효과를 측정하는 방법으로 널리 이용되고 있 다. 본 실험에서 산양삼 지상부 추출물의 tyrosinase 저해활성을 측정한 결과, Fig. 2에서와 같이 열수 추출물은 $50-200 \mu \mathrm{g} / \mathrm{mL}$ 의 농도구간에서 저해율은 $4.90-10.97 \%$ 로 다소 낮은 수준으로 증가하는 양상을 나타내었고, 에탄올 추출물의 경우에는 50-100 $\mu \mathrm{g} / \mathrm{mL}$ 의 농도구간에서 저해율이 $43.64-44.46 \%$ 로 서로 유사하 게 나왔고, $150-200 \mu \mathrm{g} / \mathrm{mL}$ 의 농도구간에서는 저해율이 $48.42-$

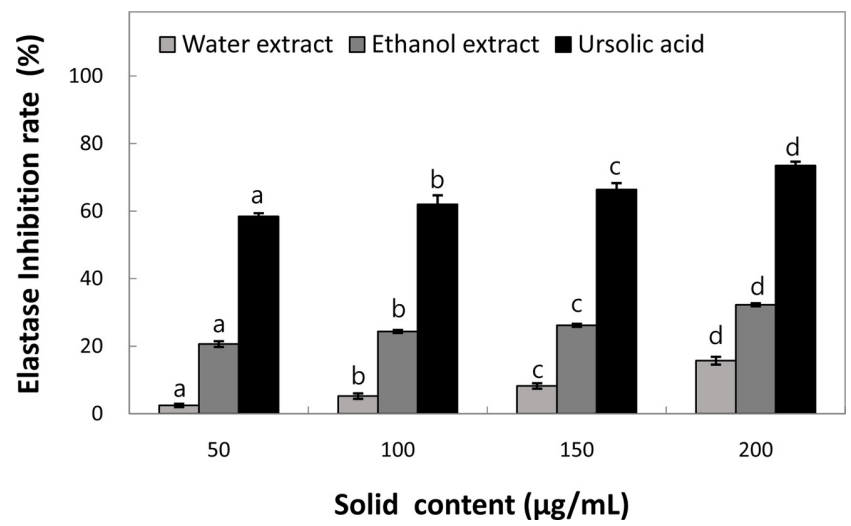

Fig. 3 Inhibitory effect of water and ethanol extracts from Panax ginseng C.A. Meyer on elastase. Ethanol extract showed higher tyrosinase inhibitory effect than water extract. Means with different superscript letters are significantly different at $p<0.05$ by a Duncan's multiple range tests $(n=3)$

$52.39 \%$ 로 첨가 농도가 높아질수록 저해율이 다소 높아지는 양 상을 나타내었다. Hwang 등(2013)의 실험에서는 $10,000 \mu \mathrm{g} / \mathrm{mL}$ 농도의 인삼 지상부 에탄올 추출물의 tyrosinase 저해활성이 $18 \%$ 를 나타내었다고 보고되는데, 50 배 낮은 농도인 $200 \mu \mathrm{g} / \mathrm{mL}$ 에서의 산양삼 지상부의 에탄올 추출물은 $52.39 \%$ 를 나타낸 것 을 미루어 보아 인삼보다 산양삼 지상부의 에탄올 추출물이 tyrosinase 저해활성이 더 우수하다는 것을 알 수 있었다.

\section{산양삼 지상부 추출물의 elastase 저해활성}

Elastin은 진피 내에서 피부의 탄력을 유지하는데 중요한 기질 단백질로, collagen과 그물망 구조로 결합된 상태로 존재한다. Elastase는 elastin과 collagen을 분해하여 그물망 구조를 파괴하 여 피부에 주름을 유발하는 비특이적 가수분해 효소이다 (Kligman 2000). 따라서 elastase 저해활성을 측정하여 피부 주 름개선 효과를 알아볼 수 있다. 산양삼 지상부 추출물의 elastase 저해활성을 측정한 결과, Fig. 3에서와 같이 $50-200 \mu \mathrm{g} / \mathrm{mL}$ 의 농 도구간에서 열수 추출물은 $2.4-15.71 \%$, 에탄올 추출물은 20.62$32.26 \%$ 로 모두 농도 의존적으로 증가하는 것을 확인할 수 있 었고, 이러한 결과를 통해 산양삼 지상부 열수 추출물보다 에 탄올 추출물의 elastase 저해활성이 더 우수한 것으로 나타나 산 업적으로 이용하는데는 에탄올 추출물이 더 유리할 것으로 판 단되었다.

\section{산양삼 지상부 추출물의 collagenase 저해활성}

피부의 섬유아세포의 작용에 의해 합성되어 진피층의 $90 \%$ 를 차 지하고 있는 collagen은 세포외 기질의 주요 구성성분이자 피부 를 보호하는 역할을 하고(Chung 2003), collagenase에 의해 분 해된다(Grant와 Alburn 1959). Collagen은 피부의 주름 생성과 관련이 있으며, 만약 부족할 경우에는 주름이 유발될 수 있어 (Kim 등, 2008), collagenase 저해활성을 측정하여 피부 주름개 선 효과를 알아볼 수 있다. 산양삼 지상부 추출물의 collagenase 저해활성을 측정한 결과, Fig. 4에서와 같이 열수 추출물은 50$200 \mu \mathrm{g} / \mathrm{mL}$ 의 농도구간에서 저해율은 3.52-20.43\%로 증가하였고, 에탄올 추출물의 경우 동일한 농도구간에서 저해율이 52.37- 


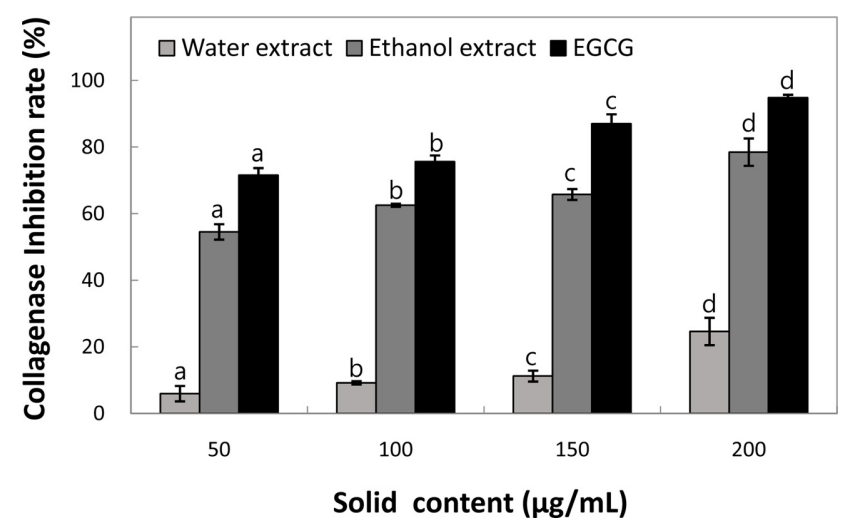

Fig. 4 Inhibitory effect of water and ethanol extracts from Panax ginseng C.A. Meyer on collagenase. Ethanol extract showed higher tyrosinase inhibitory effect than water extract. Means with different superscript letters are significantly different at $p<0.05$ by a Duncan's multiple range tests $(n=3)$

$86.74 \%$ 로 농도 의존적으로 증가하는 것을 볼 수 있다. $200 \mu \mathrm{g}$ $\mathrm{mL}$ 의 농도에서 열수 추출물과 에탄올 추출물의 저해율이 각각 $20.43,86.74 \%$ 인 것을 보아 산양삼 지상부의 에탄올 추출물이 열수 추출물보다 collagenase 저해활성이 더 우수한 것을 확인 할 수 있었으며, positive control인 epigallocatechin gallate와 유사한 수준의 효능을 나타내는 것을 알 수 있었다. Kim 등 (2012)의 실험에 따르면 숙성한 인삼 에탄올 추출물의 collagenase 저해활성은 $100 \mu \mathrm{g}$ 에서 $49 \%$ 의 활성을 보였다고 한다. 본 실험 에서는 동일한 농도에서 에탄올 추출물이 $62.52 \%$ 를 나타낸 것 으로 보아, 산양삼 에탄올 추출물의 collagenase 저해활성이 더 우수한 것을 알 수 있었다. 따라서 산양삼 지상부의 에탄올 추 출물은 피부의 주름을 개선시키는 미용 식품의 원료로서 사용 이 가능할 것으로 기대된다.

이상의 결과를 종합하여 보면, 산양삼 지상부의 에탄올 추출 물은 수용성보다 지용성 물질에 대한 항산화 효과가 우수하여 oil 성분을 위주로 하는 화장품 제형에 더욱 잘 어울릴 수 있는 소재로 판단되며, 미백 효과와 주름개선 효과도 우수하여 미용 식품 또는 기능성 화장품의 소재로 활용도가 높을 것으로 판단 되었다.

\section{초 록}

본 연구에서는 산양삼 지상부(줄기, 잎)의 동결건조물 함량을 달 리하여 열수 추출물과 $70 \%$ 에탄올 추출물을 제조하고, 항산화, 피부 미백 및 주름 개선 활성을 측정하여 미용 식품의 원료로 사용하기 위한 기초자료를 제공하고자 하였다. 산양삼 지상부 열수, 에탄올 추출물은 $200 \mu \mathrm{g} / \mathrm{mL}$ 농도에서 DPPH radical 저 해율은 각각 $16.69,2.18 \%$ 를 나타내었고, ABTS radical 저해율 은 각각 4.04, 3.25\%를 나타내었다. $200 \mu \mathrm{g} / \mathrm{mL}$ 농도에서 열수 및 에탄올 추출물의 $\mathrm{PF}$ 가 각각 $1.06,1.09 \mathrm{PF}$ 를 나타내었고, TBARs는 모두 $96 \%$ 정도의 활성을 나타내었다. PF와 TBARs 가 $\mathrm{DPPH}$ 와 $\mathrm{ABTS}$ 보다 우수한 활성을 나타낸 것을 통하여 산 양삼 지상부 추출물은 지용성 물질에 대한 항산화능이 더 뛰어
나다는 것을 알 수 있었다. 열수 및 에탄올 추출물의 elastase와 collagenase 저해율은 $200 \mu \mathrm{g} / \mathrm{mL}$ 농도에서 각각 $15.71,32.26 \%$ 그리고 $20.43,86.74 \%$ 를 나타내었다. Tyrosinase 저해율은 200 $\mu \mathrm{g} / \mathrm{mL}$ 의 농도에서 각각 $10.97,52.39 \%$ 를 나타내었다. 이러한 결과에 따라 산양삼 지상부 추출물의 주름 개선 효과가 특히나 우수한 것을 알 수 있었으며, 피부의 주름을 개선시키는 새로 운 미용 식품의 원료로서 사용이 가능할 것으로 기대된다.

Keywords 미백효과·미용식품·산양삼·주름개선·항산화 활성

\section{References}

Andarwulan N, Shetty K (1999) Phenolic content in differentiated tissue cultures of untransformed and agrobacterium-transformed roots of anise (Pimpinella anisum L.). J Agric Food Chem 47: 1776-1780

Bae MJ (2010) Assessment of ecological characteristics and development of wellbing functional product with leaves and roots of mountain-cultivates ginseng. Report of Korea Forest Service, Daejeon, Korea

Blios MS (1958) Antioxidant determination by the use of a stable free radical. Nature 26: 1199-1200

Buege JA, Aust SD (1978) Microsomal lipid peroxidation. Methods Enzymol 105: 302-310

Cheon SJ, Jang MJ, Jang YA, Choi EY, Jun DH, Kim YH, Cho WA, Jeong YS, Kwon HB, Kim TH, Choi KI, Do JR, Lee CE, Lee JT (2008) Antiwrinkle effect of Cambodian Phellinus linteus extracts. J Life Sci 18: 1718-1722

Cho YJ, Chun SS, Lee KH, Kim JH, Kwon HJ, An BJ, Kim MU (2006) Screening of the antimicrobial activity against Helicobacter pylori and antioxidant by extracts from mulberry fruits (Morus albba L.). J Korean Soc of Food Sci and Nut 35: 15-20

Chung JH (2003) Photoaging in asians. Photodermatol photoimmunol photomed 19: 109-121

Cojocaru IM, Cojocaru M, Musuroi C, Botezat M, Lazar L, Druta A (2004) Lipid peroxidation and catalase in diabetes mellitus with and without ischemic stroke. Rom J Intern Med 42: 423-429.

Curri SB, Gezzi A, Longhi MG, Castelpietra R (1986) Dermocosmetic activity of ginsenosides. Note III: Long term evaluation of the moisturizing and tonifying effect on the face skin. Fitoterapia 57: 217222

Fellegrin N, Ke R, Yang M, Rice-Evans C (1999) Screening of dietary carotenoids and carotenoid-rich fruit extracts for antioxidant activities applying 2,2'-azinobis(3-ethylenebenzo thiazoline-6-sulfonic acid)radical cation decolorization assay. Methods Enzymol 299: 379-389

Gezzi A, Longhi MG, Mazzoleni R, Curri SB (1986) Dermocosmetic activity of ginsenosides. Note II: instrumental evaluation of cutaneous hydration and elasticity. Fitoterapia 57: 15-28

Grant NH, Alburn HE (1959) Studies on the collagenases of Clostridium histolyticum. Arch Biochem Biophys 82: 245-255

Hearing VJ Jr (1987) Mammalian monophenol monooxygenase (Tyrosinase): purification, properties, and reactions catalyzed. Methods Enzymol 142: 154-165

Hwang CR, Joung EM, Lee SH, Hwan IG, Kim YB, Jeong JH, Lee J, Jeong HS (2013) Chemical components and enzyme activity of hydroponiccultured ginseng roots and leaves under different heating temperatures. J Korean Soc Food Sci Nutr 42: 911-916

James AEK, Timothy DWC, Gorden L (1996) Inhibition of human leukocyte and porcin pancreatic elastase by homologues of bovine pancreatic trypsin inhibitor. Biochem J 35: 9090-9096

Jeong SC, Park JH, Kim JH (2013) The development trend of skin beauty food with skin protection effects from natural source. Kor J Aesthet Cosmetol 11: 71-80 
Kang TH, Park HM, Kim YB, Kim HA, Kim N, Do JH, Kang CH, Cho YH, Kim SY (2009) Effects of red ginseng extract on UVB irradiationinduced skin aging in hairless mice. J Ethno Pharmacol 123: 446-451

Kazumasa W, Shosuke I (2002) Advanced chemical methods in melanin determination. Pigment Cell Res 15: 174-183

Kim DH, Moon YS, Son JH (2015) Verification of anti-oxidative activity of Aruncus dioicus a native plant of Ulleungdo. J Plant Biotech 42: 55-59

Kim EA (2007) Phytochemicals and beauty food. Food science and industry 40: 3-9

Kim HK, Kim YE, Do JR, Lee YC, Lee BY (1995) Antioxidative activity and physiological activity of some Korean medicinal plants. Korean J Food Sci Technol 27: 80-85

Kim ID, Kwon RH, Heo YY, Jung HJ, Kang HY, Ha BJ (2008) Supercritical extraction of oriental herb: anti-aging and anti-wrinkle effects. KSBB Journal 23: 529-534

Kim JH, Kim JK (2005) Effect of extracting conditions on chemical compositions of Korean mountain ginseng extract. J Korean Soc Food Sci Nutri 34: 862-868

Kim K (2015) Effect of ginseng and ginsenosides on melanogenesis and their mechanism of action. J Ginseng Res 39: 1-6

Kim MJ, Kwon RH, Jang MW, Ha BH (2012) Antioxidant and anti-wrinkle effects of steamed thress ginseng extracts. J Soc Cosmet Scientists Korea 38: $155-162$

Kim NM, Koo BS, Lee SK, Hwang EI, So SH, Do JH (2007) Effect of Korean red ginseng on collagen biosynthesis and MMP-I activity in human dermal fibroblast. J Ginseng Res 31: 86-92

Kligman D (2000) Cosmeveuticals. Am J Clin Dermatol 18: 609-615

Kwok HH, Yue PY, Mak NK, Wong RN (2012) Ginsenoside Rb(1) induces type I collagen expression through peroxisome proliferator-activated receptor-delta. Biochem Pharmacol 84: 532-539

Lee DS (2011) Theory and practice of growing forest cultivated ginseng. Nexus Publish, Paju

Lee EH, Cho SY, Kim SJ, Shin ES, Chang HK, Kim DH, Yeom MH, Woe KS, Lee JS, Sim YC, Lee TR (2003) Ginsenoside F1 protects human HaCaT keratinocytes from ultraviolet-B-induced apoptosis by maintaining constant levels of Bcl-2. J invest dermatol 121: 607-613

Lee SE, Lee SW, Bang JK, Yu YJ, Seong NS (2004) Antioxidant activities of leaf, stem and root of Panax ginseng C. A. Meyer. Korean J. Medicinal Crop Sci 12: 237-242

Oh JY, Park LG, Song DH, Yeom MH, Jo YK (1998) Cosmetic composition containing extract of Panax ginseng C.A Meyer for prevention of skin aging. Patent 1003614330000, November 2002, Korea

Pan HY, Qu Y, Zhang JK, Kang TG, Dou DQ (2013) Antioxidant activity of ginseng cultivated under mountainous forest with different growing years. J Ginseng Res 37: 355-360

Park HJ, Byeon HE, Choi KW, Rhee DK, Lee KR, Pyo SN (2010) Inhibitory effects of ginsenoside $\mathrm{Rb} 1$ on atopic dermatitis-like skin lesions in mice. J Ginseng Res 34: 363-368

Park JS (2007) Skin barrier and beauty foods. Food Science and Industry 40: $19-26$

Shosuke I (2003) A chemist's view of melanogenesis. Pigments Cell Res 16: 230-236

Wunsch E, Heindrich HG (1963) Zur qutitativen bestimmung der collagenase. Hoppe-Seyler's Physiol chem 333: 149-151

Yeom MH, Lee JY, Park NH, Park JS, Kim DH, Kim HG (2016) Composition for applying skin externally containing extract from flower of ginseng. Patent 101775220000 , February 2017, Korea 